\title{
"PARA NO OLVIDAR": HUACAS DISFRAZADAS. LA APARIENCIA EUROPEIZANTE DE LAS DIVINIDADES ANDINAS EN LOS QUEROS COLONIALES DE MADERA POLICROMADOS (SIGLOS XVI D.C. AL XVIII D.C.)
}

\author{
“NOT TO FORGET”: HUACAS DISGUISED. THE EUROPEAN APPEARANCE \\ OF THE ANDEAN DIVINITIES INTO THE COLONIAL POLYCHROME \\ WOODEN QUERO VESSELS (16TH-18TH CENTURY A.D.)
}

Manuel A. Lizárraga Ibáñez*

\begin{abstract}
Los queros coloniales de madera policromados (llimpisccaqueros) fueron materialidades que soportaron discursos visuales ceremoniales de las élites andinas contemporáneas (sus principales emisores). Así, a raíz de la "conquista visual” española, este sistema de soporte de memoria de origen prehispánico reaccionó rápidamente ante los estímulos visuales de la pintura y hermenéutica de la imagen europea del Cinquecento (de la pintasca). Debido al uso local de estampas, grabados y libros ilustrados europeos, los queros coloniales de madera policromados capturaron algunas imágenes fabulosas europeas de origen clásico de reproducción renacentista para reconfigurar, con ellas, su imaginario andino colonial. De esta manera se tienen "vasos de palo" que, como parte de su nuevo universo simbólico, presentan significantes andinos coloniales de aspecto europeizante que no se ajustan formalmente al vero ícono transatlántico, sino, más bien, corresponden a verdaderas variaciones locales - "ficciones"- que si bien se diferencian de sus modelos europeos guardan, a su vez, una clara herencia grecorromana y renacentista. Dentro de este escenario estético, los artesanos de estos "vasos de palo" utilizaron ciertas imágenes de El Fisiólogo-Bestiario Medieval (sirenas, centauros por ejemplo) para dibujar significantes fabulosos que pudieran copar, de manera alegórica, el vacío simbólico dejado por el aniquilamiento de las huacas locales de las élites andinas coloniales producto de la conquista española.
\end{abstract}

Palabras claves: Apropiación iconográfica, queros de madera policromados, huacas andinas coloniales, Bestiario Medieval.

The colonial polychrome wooden quero vessels (called llimpisccaqueros) were a type of materiality that support ceremonial visual discourses of Andean contemporary elites (their main transmitters). Thus following the Spanish "visual conquest", this pre-Hispanic memory support system reacted quickly to visual impulses of European Cinquecento image (to pintasca) paintings and hermeneutic. Due to local use of European stamps, engravings and illustrated books; the colonial polychrome wooden quero vessels captured some Classic European fabulous images of Renaissance reproduction for reconfiguring, with them, its Andean colonial imaginary. In this way we have "vasos de palo", as part of their new symbolic universe, that present Andean colonial signifiers of European appearance which are not formally fit to transatlantic icon vero but, rather, correspond to real local variations - "fictions" - that although differ from their European models saved, in turn, a clear Greco-Roman and Renaissance heritage. Inside this aesthetic scenery, the artisans of their "vasos de palo" used certain images of The Physiologist-Medieval Bestiary (sirens and centaurs for example) for drawing fabulous signifiers that could surround, allegorically, the symbolic vacuum left by the annihilation of the local huacas of the Colonial Andean elites, during the Spanish conquest.

Key words: Iconographic appropriation, polychrome wooden quero vessels, Andean colonial huacas, Medieval Bestiary.

\section{Introducción}

La invasión española al Tahuantinsuyo (en 1532 d.C.) fue, entre otras, una "conquista visual" que trajo consigo no solo la llegada de nuevas convenciones $^{1}$ y significantes visuales europeos ${ }^{2}$, sino también el arribo de distintos imaginarios procedentes del Viejo Mundo ${ }^{3}$; como por ejemplo: las criaturas fabulosas de origen clásico de reproducción y parafraseo renacentista (Panofsky 1983) reunidas y visualizadas, para los "ojos imperiales" de la época en: El Fisiólogo-Bestiario Medieval (véase al unicornio dibujado en la versión ilustrada del "Bestiario Medieval", manuscrito de Oxford 1511: Biblioteca Bodleian fol. 21 r., en: Malaxecheverría 1996; ver nuestra Figura 1) ${ }^{4}$.

"El Fisiólogo" es un libro que describe todo tipo de animales, entre reales y fantásticos, entre naturales e inverosímiles, que habitan una delirante geografía ${ }^{5}$. No se trata de un texto científico, pues

\footnotetext{
* Ministerio de Cultura del Perú, Lima, Perú. Correo electrónico: lizarraga.ma@ pucp.edu.pe
} 


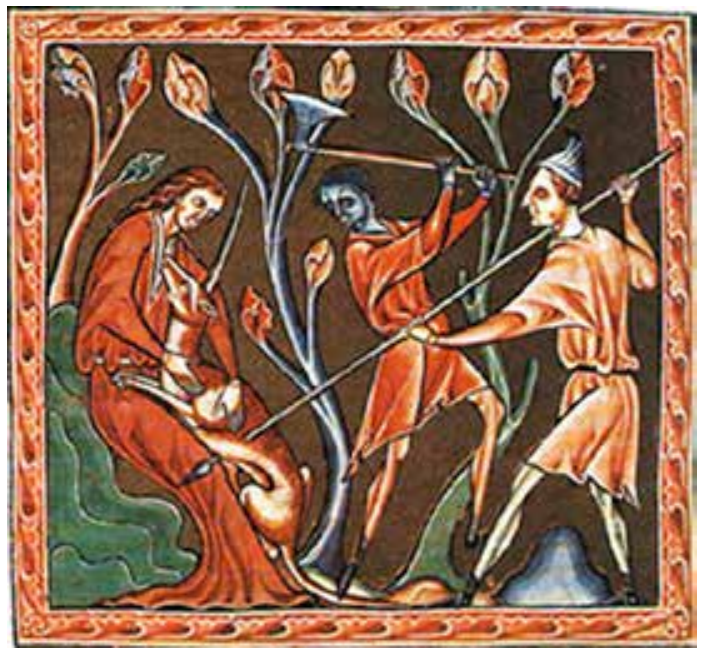

Figura 1. Unicornio (Monocero): monstruos e híbridos. Tomado de la versión ilustrada del "Bestiario Medieval"-manuscrito de Oxford 1511 (Biblioteca Bodleian fol. 21 r.).

deriva de la imaginación colectiva que, para el caso de este libro de origen griego (por estar posiblemente escrito en Alejandría), provenía de diversas fuentes inventivas como las indias, judías, egipcias, griegas y cristianas (Anónimo 2000). Es un texto que contiene imágenes mentales imaginadas - phantasmatas $^{6}$ - con explicaciones moralizantes cargadas de un marcado simbolismo católico que fueron utilizadas, en el Viejo Mundo, para evangelizar a la gente pagana; razón por la que, al producirse la conquista del Tahuantinsuyo y el contacto con las poblaciones indígenas (consideradas "paganas" para las huestes de Pizarro), las mismas imágenes mentales de origen europeo (tanto gráficas como textuales) fueron utilizadas como modelos coloniales para catequizar y colonizar el imaginario andino. Con dicha asimilación eurocéntrica, las criaturas fabulosas de origen clásico se instalaron rápidamente en el imaginario local del siglo XVI d.C. favoreciendo, con dicho despliegue, a la difusión de la visualidad europea (de sus formas y convenciones) ${ }^{7}$ por todo los Andes. En virtud a ello señalamos que, El Fisiólogo-Bestiario Medieval estuvo ligado, como libro y fuente iconográfica, al poder colonial en "las Indias".

En efecto, la "conquista visual" española provocó la transmigración iconográfica de carácter continental de varios significantes fabulosos del Viejo Mundo al Tahuantinsuyo. Así, criaturas cuyos orígenes se remontan a tiempos y espacios tan lejanos como la Roma del poeta latino Publio Ovidio Nasón (43
a.C-17 d.C. $)^{8}$ viajaron, por la historia y los continentes, hasta llegar a los Andes sudamericanos del siglo XVI d.C. (manteniendo aún lo esencial de su aspecto original según Stastny 1965).

La "política visual" conquistadora también influyó en la (re)inscripción y materialización de la memoria andina colonial ${ }^{9}$, pues, según la historiografía renacentista contemporánea de la época, por medio de la pintura mimética ${ }^{10}$ se podía registrar "lo real" de las palabras y cosas sucedidas. Con toda esta hermenéutica ${ }^{11}$ el periodo colonial fue, además, un choque de experiencias visuales heterogéneas en la manera de registrar e imprimir, siguiendo a Frances Yates (2005: 9-45): el "arte de la memoria"12 en los diferentes soportes y materialidades locales. Precisamente a raíz de este esfuerzo eurocéntrico por controlar la memoria indígena se desató, en los Andes de los siglos XVI d.C. al XVIII d.C., una lucha representacional por configurar lo real y sobrenatural del Nuevo Mundo (Kaulicke 2003), así como por memorizar y recordar "lo natural" de sus cosas y palabras (Yates 2005).

A pesar del esfuerzo español por tratar que sus códigos pictóricos eliminen -"devoren"13 - las lógicas de representación prehispánicas (haciendo que los indígenas del Perú pudiesen "pintar con la curiosidad que tienen los de allá [de Europa]" al decir de Iwasaki Cauti 1986: 67); hubo espacios donde precisamente las materialidades y mentes locales siguieron representando y dibujando: "como si no hubiese habido conquista" (Cummins 2004: 226). Así, en los Andes coloniales (siglos XVI d.C.-XVIII d.C.) se tiene, al margen de la letra y de la intelectualidad hegemónica española, todo un conjunto nativo de sistemas de soporte ${ }^{14}$ (como los queros de madera pintados de manera policromada conocidos como llimpisccaqueros; ver Figura 2) $)^{15}$ que, con lenguajes diferentes a los de la escritura alfabética (como los visuales), siguieron circulando y plasmando las "voces andinas" ahora coloniales (en especial: las versiones de cada una de las élites incaicas descendientes; véase Lizárraga 2009 y Martínez 2008a, 2011). De esta manera los querocamayocs contemporáneos, aquellos artesanos nativos designados en la época colonial como especialistas en la elaboración de estos "vasos de palo" de prestigio que aún se mantenían bajo la tutela de la nobleza local (cf. más adelante), permanecieron fieles -más resistentes- a sus propias lógicas de representación de raíces incaicas incluso años después de la conquista hispana (Rowe 1976). 


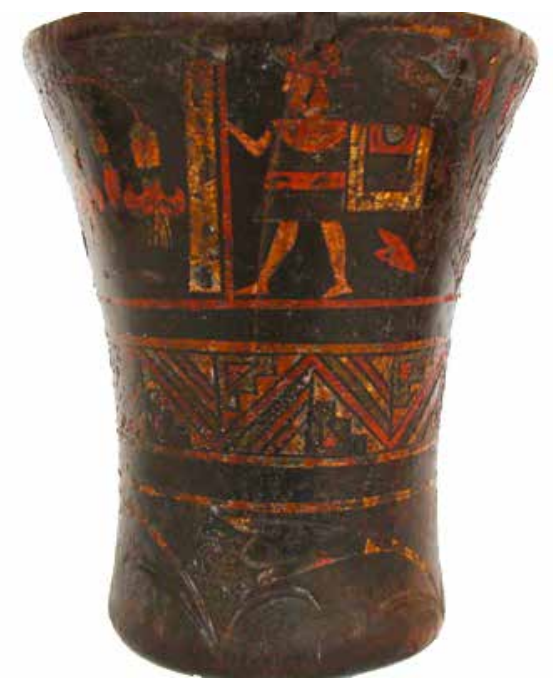

Figura 2. Quero de madera policromado del siglo XVI d.C. (pieza MOMAC 88 del Museo Inka de la UNSAAC del Cuzco).

Pero ¿qué significó pintar a la usanza española del siglo XVI d.C. ${ }^{16}$ Pintar de manera mimética ${ }^{17}$ era considerado, por los conquistadores españoles y para todo hombre del Renacimiento, como una manera de recordar y almacenar lugares e imágenes en la memoria colectiva; herramientas visuales necesarias para fortalecer la retórica colonizadora. Por tanto la pintura del Renacimiento (la pintasca según el informante nativo Cristóbal Choque Casa ${ }^{18}$ ) fue utilizada, entre otras cosas, para controlar la memoria andina colonial. Entonces hacer que los indígenas del Perú pudiesen pintar con la destreza y el registro que tenían los ultramarinos fue, a su vez, una manera que tuvieron los colonizadores españoles para controlar la memoria y direccionar la visualidad local hacia pautas renacentistas de registro (hacia modelos que los conquistadores conocían y entendían acerca de ¿cómo debía pintarse un recuerdo? Mignolo 1992, 1995).

Sin embargo, y a diferencia de lo planteado por el "proyecto visual colonial", los llimpisccaqueros de la época (así como otros sistemas de soporte de memoria de origen precolombino) sí lograron circular fuera de la intelectualidad hegemónica europea, manteniéndose al "margen de la letra" y continuar pintando con una lógica de representación prehispánica no controlada (al menos no totalmente) por las convenciones o visualidad europea (Lizárraga 2009; Martínez 2008b). A pesar de esta persistencia pictórica, y debido a las interconexiones "devorantes"19 entre códigos visuales diferentes llegados con la "conquista visual" española, los "vasos de palo" que continuaron circulando al interior del mundo colonial no lo hicieron de forma "pura" (de igual manera que en la época inca), sino con ciertas transformaciones, variaciones y readecuaciones temático-formales producto del impacto visual y representacional del nuevo canon y decorum artístico español (muy ligado, este último, a la visualidad y "arte de memoria" renacentista como manierista). Entonces a raíz de la "conquista visual" española, la estética de los queros coloniales de madera fue reconfigurada con gran capacidad simuladora por sus mismos artesanos nativos con la finalidad de mantenerlos en circulación y evitar, así, la represión política y confiscación eclesial.

En efecto, a raíz del impacto representacional europeo cristiano y su manera de imprimir en la memoria local colectiva varias imágenes y lugares comunes, los "vasos de palo" de representación inca sufrieron autotransformaciones estético-culturales que fuesen aceptadas por el ojo y memoria hispana. Así, y utilizando una "cronología estilística" 20 para su datación (véase Cummins 1995 y Rowe 1961), tenemos (Figura 3): de piezas incaicas de madera sin mucho color y decoradas principalmente con imágenes geométricas abstractas lineales incisas (tocapus) se pasó, previa experimentación con los queros de la transición ${ }^{21}$, a "vasos de palo" con escenas narrativas figurativas pintadas en bajorrelieve de forma realista y colorida (from abstraction to narration, según Cummins 1988).

Como parte de estas transformaciones pictóricas, la ontología de la imagen de los queros coloniales de madera policromados también se readecuó a su similar europea, pues dejando, no del todo, la ontología de la imagen andina (el $c_{a m a c}{ }^{22}$ ) y atendiendo ahora la de la pintasca europea renacentista y manierista (la imagen como representación y figuración de la realidad): trataron las figuras ahí dibujadas como significantes realistas que formalmente signifiquen por mimesis ${ }^{23}$ (como por ejemplo: la escena "Baile de Chunchos", véase piezas hermanadas R1161 y R1162-Figura 4). De este manera, y siguiendo la visualidad renacentista-conquistadora con su capacidad de registro para recordar gráficamente cosas y palabras, los queros coloniales de madera hicieron suyas aquellas imágenes exóticas que les parecían sorprendentes, pero que a su vez, paradójicamente, se las imponían desde el poder colonial; con los que los llimpisccaqueros de la época pudieron pintar 
3A

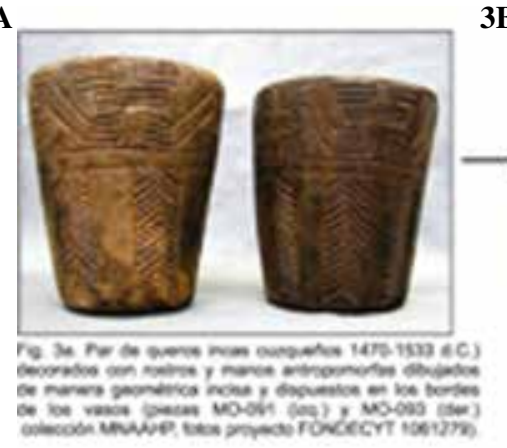

3B

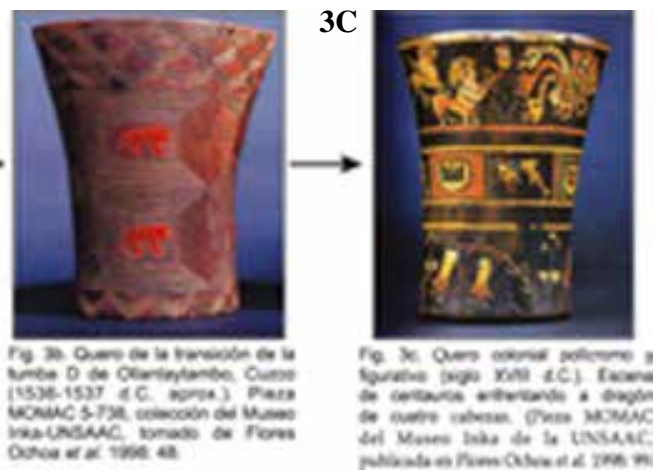

Figura 3. De figuras geométricas a escenas narrativas: traducción estética y cultural de los queros de madera (siglos XVI d.C. al XVIII d.C.).

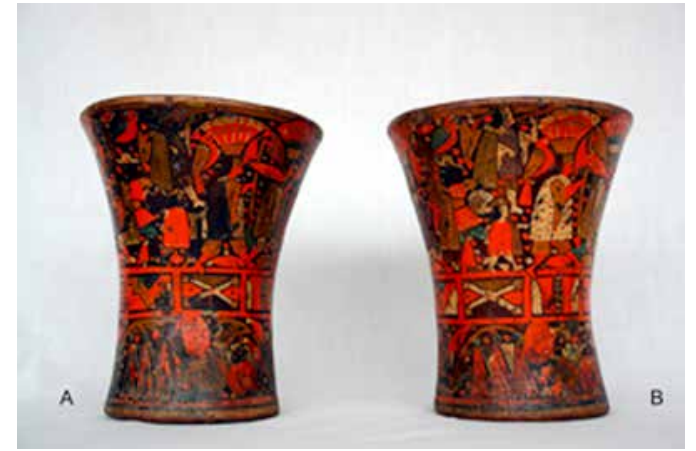

Figura 4. Llispisccaqueros andinos coloniales (siglo XVII d.C.). "Vasos de palo" figurativos pintados bajorrelieve con la técnica "laca incrustada" y organizados, estos 2 ejemplares, en tres campos horizontales (piezas hermanadas R1162 (A) y R1161 (B) del Museo de Etnografía y Folklore (MUSEF) de la ciudad de La Paz-Bolivia, fuente Proyecto FONDECYT 1090110).

dibujos activos que resaltasen por su hermosura o deformidad, comicidad u obscenidad, ante la vista y memoria de sus lectores y veedores nativos (SallesReese 2008; Yates 2005). Con dicha capacidad de registro, los llimpisccaqueros coloniales contuvieron significantes con anotaciones de relatos de memoria inscritos en ellos.

\section{Los queros: un sistema de soporte de memoria de origen prehispánico en el contexto colonial}

Los queros fueron -principalmente- vasos de madera considerados como objetos simbólicos y usados por diferentes sociedades andinas precolombinas, especialmente la inca (1470-1533 d.C.). Las piezas incaicas en particular (Figura 5) corresponden a vasos de madera, cerámica, piedra, oro y plata (estos dos últimos conocidos como aquillas; véase Anónimo 1951 [1586]: 17; Bertonio 1984,

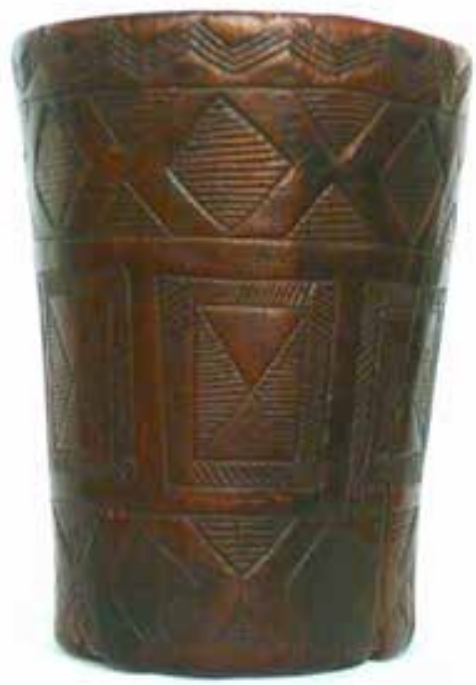

Figura 5. Quero incaico de madera (1470-1533 d.C.) con decoración geométrica abstracta lineal incisa sobre fondo de madera natural (pieza IV-2.3-0593 del Museo de Arte de Lima (MALI), fuente Proyecto FONDECYT 1090110).

II parte: 290 [1612]; González Holguín 1952: 33 [1608]), que tuvieron una decoración altamente uniforme. En efecto, los ejemplares incaicos de madera presentan, mayoritariamente, significantes abstractos geométricos lineales incisos así como rostros y manos antropomorfas dibujadas también de manera geométrica incisa, pero dispuestos en los bordes de los vasos (regresar a Figura 3a) y, en menor medida, significantes geométricos pintados en bajorrelieve con la técnica de "laca incrustada". Las piezas de cerámica muestran, igualmente, diseños geométricos pintados sobre la superficie del vaso ${ }^{24}$ así como motivos esquemáticos en alto 
relieve (como banda de llamas en Flores Ochoa et al. 1998: XX), además de seres antropomorfos y zoomorfos pintados sobre la superficie del vaso de cerámica (revisar figuras en Fernández Baca 1971, tomo I: 17).

Con el término "abstracción geométrica lineal incisa" me refiero a aquellos significantes visuales sin referentes reales conocidos para los conquistadores españoles del siglo XVI d.C. ni investigadores actuales. Es decir, conjunto de formas geométricas (no figurativas ni miméticas) que en la mayoría de los casos no guardan relación visual evidente con los seres u objetos del mundo sensible conocido, puesto que los significantes incas no imitaban ni estaban cercanos a la naturaleza. A pesar de esta característica visual, la abstracción lineal incaica fue un lenguaje formal de representaciones que sí funcionó como un sistema comunicativo de "significado semasiográfico convencional"; esto es: significantes visuales que no registran la totalidad del habla, no llegan a igualar a esta, sino que transmiten ideas, conceptos y discursos consensualmente aceptados y leídos en todos sus niveles de significado solo por aquellos quienes están insertos en su sintaxis representacional y lógica de disposición (ver Boone 1994; González y Bray 2008; Salomon 2001).

Con estos significantes visuales (abstractos lineales) y su respectiva facultad de registro (semasiográfico convencional) los queros incásicos de madera contuvieron "imágenes de memoria"; donde esta última ${ }^{25}$ estaba educada por medio del arte y materializada, a su vez, en el paisaje y arquitectura pero sin contar con el apoyo de la imprenta (Yates 2005). Debido a ello, los queros incásicos funcionaron como un "sistema de soporte" de memoria; esto es, siguiendo a Martínez (2008a, 2011), objetos sensibles, tangibles y discretos - materialidades de índole estatal como regional- que registran y almacenan informaciones religiosas así como temáticas vinculadas al poder, identidad y memoria social particular (en este caso de las panacas incaicas descendientes, según Lizárraga 2009). Sistema de registro que articula y enuncia relatos (mediante su lenguaje visual); es decir, "sistemas de comunicación que incluyen el registro y la transmisión de información [pero] que no utilizan la materialidad y la tecnología de la escritura alfabética" (QuispeAgnoli 2008: 134).

Por tanto, los significantes abstractos lineales funcionaron, en los queros incaicos de madera, como señales precisas cargadas de información que despertaron y estimularon la memoria de las sociedades incaicas (especialmente de la élites locales, sus principales lectores) constituyéndose en imágenes que fácilmente pudieron adherirse a la memoria visual de sus veedores y usuarios por largo tiempo (Yates 2005), instalando, con dicha presencia temporal, el repertorio iconográfico indígena en los queros de madera. Al decir de los primeros informes virreinales y eclesiásticos de la zona centro-sur del Perú ("La visita general hecha por el Virrey Toledo [entre 1570 y 1575]" o "La instrucción para descubrir todas las guacas del Pirú y sus camayos y haziendas" (ca. 1582) de Cristóbal de Albornoz), los queros fueron objetos idolátricos que retuvieron, a modo de archivos visuales, "imágenes de memoria" que ayudaban a recordar relatos o la entera "cosa" idolátrica, ya que permitían, a los indígenas, volver a retomar sus ritos y hechos del pasado. Por tanto, fueron "vasos de palo" con gran capacidad para evocar y rememorar información del pasado, pues por medio de sus "imágenes de memoria" se podían contar relatos del pasado (de tinte ceremonial). Es por eso que Martínez (2008b: 157) propone que los queros de los siglos XVI d.C. y XVII d.C. funcionaron como "textos que activaban una determinada memoria social, al menos de la cuzqueña”. Pero ¿qué tipo de enunciaciones visuales?

\section{Registro y visualidad en los queros coloniales de madera policromados tipo llimpisccaquero}

Los queros coloniales fueron materialidades que ejercitaron y ayudaron, mediante sus "imágenes de memoria" (corpus de imaginería), al registro de impresiones y eventos del pasado tawantinsuyano; razón por la que su circulación y uso estuvo controlada y restringida por el poder español. Con este escenario estético adverso las élites incaicas descendientes supieron, con gran capacidad simuladora, alimentarse de los códigos visuales y estéticos de los conquistadores europeos para reconfigurar, con ellos, la imaginería de sus "vasos de palo" y poder así siguiéndolos circular. De este modo, y como una de las herramientas visuales que tuvieron las élites locales para transformar la imaginería inca de sus "vasos de palo" en otra que fuese más aceptable para el "ojo conquistador", se tienen: las figuras fabulosas europeas de El Fisiólogo-Bestiario Medieval (como la del unicornio, regresar a Figura 1). Precisamente a razón de su profuso despliegue eurocéntrico no es 
raro que, al momento de producirse la llegada de Francisco Pizarro al Tahuantinsuyo (ca. 1532 d.C.) y el posterior establecimiento del virreinato del Perú, las imágenes gráficas y textuales de centauros, sirenas y dragones (entre los más representativos) hayan arribado de inmediato a los Andes sudamericanos del siglo XVI d.C. y forzado "puntos de encuentro" entre ambas tradiciones figurativas y mitológicas (la andina y de Viejo Mundo). Así, por ejemplo, la sirena europea fue asimilada como las "representantes pisciformes de Copacabana" (peces sensuales y lascivos con atributos femeninos que merodean el lago Titicaca) llamadas Quesintuu y Umantuu (Gisbert 1980).

Debido a su gran aceptación en la Europa de los conquistadores españoles El Fisiólogo-Bestiario Medieval fue, junto a la Biblia, uno los libros más leídos y consultados de la época (Anónimo 2000: 10; Guglielmi 1971), siendo sus imágenes, tanto textuales como gráficas, cargadas con peculiares significados para las sociedades europeas del Renacimiento. A razón de su popularidad ultramarina, algunas criaturas del bestiario medieval (como el basilisco, la sirena, el unicornio, entre los más representativos) arribaron al Nuevo Mundo con su misma fama europea obteniendo, por ello, una reconocida aceptación y visibilidad colonial tan ubicua que, algunas de estas criaturas fabulosas (como el dragón readaptado y traducido localmente en forma de Tarasca-Figura 6) fueron incluso sacadas en exequias y desfiles peruanos oficiales. Esta visibilidad colonial permitió que, entre las sociedades andinas contemporáneas, se despertase la curiosidad visual

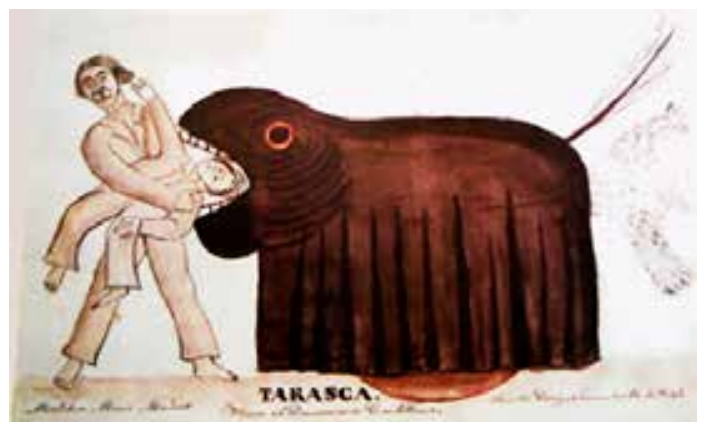

Figura 6. Tarasca imaginada por las "mentes andinas" del siglo XIX d.C. y representada en desfiles y fiestas populares locales. Criatura dibujada según el pintor, naturalista, explorador y músico boliviano Melchor María Mercado (acuarela tomada de su Álbum de paisajes, tipos humanos y costumbres de Bolivia 1841-1869). por su apropiación iconográfica; en especial por parte de los 1) indios doctos y 2) querocamayocs; dos de los principales actores sociales indígenas en este proceso nativo de captura y resemantización iconográfica del bestiario medieval europeo en los Andes según Lizárraga (2010).

Se entiende "indios doctos" como la clase erudita indígena que, desde fines del siglo XVI d.C., estuvo familiarizada con las criaturas mitológicas clásicas (propias del arte idealizado del Manierismo) sintiendo agrado por las alegorías grecorromanas. Sector educado en parte dentro de las escuelas de caciques y con acceso a sus bibliotecas; integrado por autoridades locales y miembros de las élites imperiales y regionales (como la familia Guarachi o el mismo Guaman Poma de Ayala) con conocimientos de los libros iconográficos modelos europeos traídos por las órdenes religiosas (Holland 2008) y utilizados, por ejemplo, en la pintura mural de las iglesias de indios (como Andahuailillas en Cuzco, véase De Mesa y Gisbert 2005: 114). Un ejemplo de estos "indios doctos" puede ser el cacique de Carabuco (Agustín Siñani) quien, a raíz de su interacción con el espacio urbano letrado y estar además familiarizado con la cultura clásica europea y el humanismo recuperado por el Renacimiento, fue el mentor del programa iconográfico de la pintura mural de la iglesia de indios de Carabuco (en el altiplano Perú-boliviano; véase Gisbert: 1980: Fig. 108) en donde se pueden apreciar los dibujos de Hércules y Apolo (cada uno representados por sus respectivos símbolos: la maza y el trípode) quienes personifican la sujeción de Hércules (el hombre) ante los designios divinos (Apolo), pues como hombre virtuoso cristiano que era para los humanistas, Hércules estaba encaminado a su mejoramiento espiritual (Gisbert 1980). Como dice Teresa Gisbert (1980: 96), esta compleja alegoría de la que son responsables el cura de Carabuco y el cacique indígena Agustín Siñani demuestra la gran erudición en alegorías clásicas de ambos. Es probable que el cacique Siñani haya estado influido por su hermano menor Antonio Bernabé, quien era clérigo.

Los querocamayocs, en cambio, corresponden a artesanos especializados en la época incásica, en los trabajos de madera usados como bienes suntuarios y de prestigio por el Sapa Inca (como por ejemplo: los vasos para beber en rituales y banquetes políticos -los queros-). Se trató de un trabajo colectivo ${ }^{26}$ que, 
entre los siglos XVI d.C. y XVIII d.C., permaneció fuera de la dirección intelectual colonial europea, con lo que estos "vasos de palo" se mantuvieron en manos indígenas que les permitieron seguir recorriendo sus propios circuitos de uso y no los citadinos europeizados (al margen de la letra "como si no hubiese habido conquista" (Cummins 2004: 226)); conservándose de este modo en vasos-testigos de las reciprocidades, visitas, estrategias sociales y políticas de las comunidades andinas (Cummins 2004; Martínez comunicación personal 2011). Es probable que al interior de estos talleres colectivos y debido al uso de estampas y libros iconográficos, modelos europeos dentro de ellos, los querocamayocs hubiesen tenido contacto con las imágenes gráficas del bestiario medieval que luego utilizaron para crear sus propios y nuevos diseños de seres sobrenaturales (de sus huacas locales).

Como resultado de este proceso de captura y apropiación iconográfica nativa se tienen "vasos de palo" pintados -llimpisccaqueros- así como otros objetos muebles emparentados tecnológicamente con la técnica "laca incrustada" (como los baúles), que muestran, como parte de su nuevo universo simbólico andino colonial, figuras locales basadas en modelos estéticos de los imaginarios clásico y renacentista europeos (en El FisiólogoBestiario Medieval); tales como el dragón 27 (Figura 7), centauro (regresar a Figura 3c), sirena (Figura 8), basiliscos (Figura 9), aves bicéfalas (sean águilas o cóndores; véase Fig. 10) entre las más dominantes. Estas figuras sobrenaturales indígenas fueron recreadas e imaginadas dentro de espacios mitológicos diferentes a los acaecidos en el Viejo Mundo (como ubicarlos por ejemplo

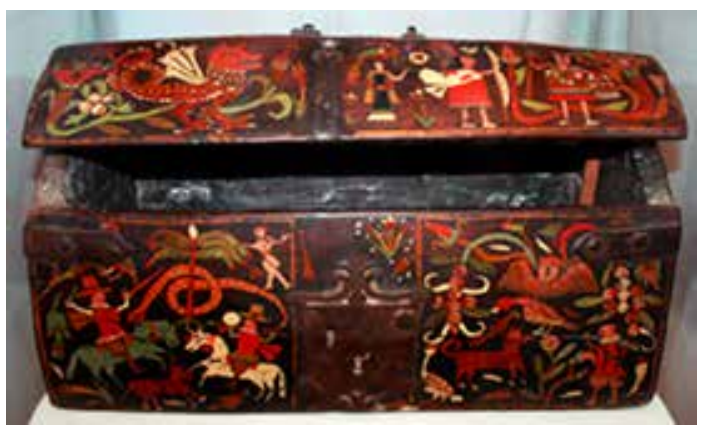

Figura 7. Dragón europeo traducido visualmente por los querocamayocs del siglo XVIII d.C. en tapa superior anterior del "Baúl de Callahuaya" (colección Museo Casa Murillo de La Paz-Bolivia, fuente Proyecto FONDECYT 1061279). Nótese también querubín en cara delantera del cajón.

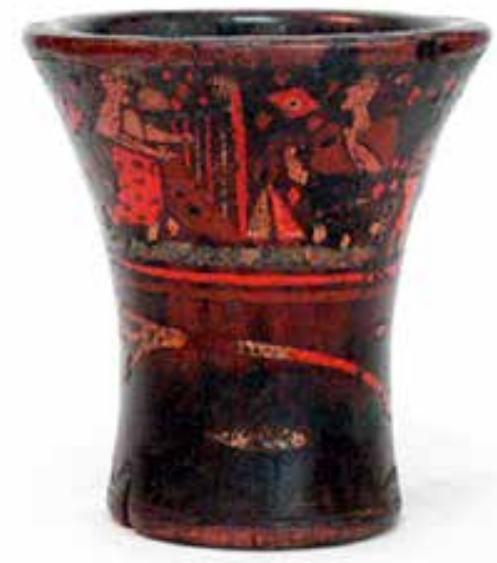

Figura 8. Par de sirenas de una (01) sola cola tocando instrumentos musicales europeos (arpa y guitarrón) dibujadas de perfil (llimpisccaquero del siglo XVII d.C, pieza MNA 1712 del Museo Nacional de Arqueología de La Paz-Bolivia, fuente Proyecto FONDECYT 1061279).

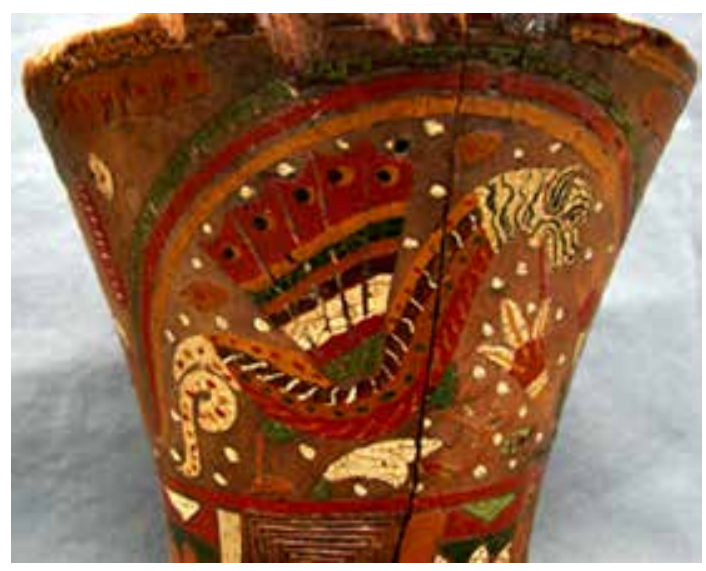

Figura 9. Detalle de basilisco debajo de motivo arco iris (kuychi) en limpisccaquero del siglo XVII d.C.: Amaru (pieza MO 10395 del Museo Nacional de Arqueología, Antropología e Historia del Perú (MNAAHP), fuente proyecto FONDECYT 1061279).

por debajo del motivo kuychi, ver Figuras 9 y $10)^{28}$. A pesar de su apariencia europeizante y muy probablemente porque los indios doctos y querocamayocs ignoraban el sentido mitológico exacto de dichas criaturas, formas y contenidos clásicos como renacentistas no se mantuvieron, en los llimpisccaqueros del siglo XVI d.C. en adelante, de forma "pura" (inalterable), sino con diversas transformaciones ("contaminaciones" según Aby Warburg 2005 [1912]); con las que estas producciones nativas basadas en modelos estéticos europeos no correspondieron a imitaciones exactas o (malas) copias del vero ícono ${ }^{29}$ europeo ni de 
su versión parafraseada en el Renacimiento, sino, más bien, a diseños locales nuevos agenciados y recreados en los Andes coloniales debido a la originalidad inventiva de sus mentores y productores locales (los indios doctos y querocamayocs). Como resultado de ello, la idea (lo imaginado) de ciertas imágenes fabulosas europeas (la cosa en sí) tuvo ligera independencia de su reproducción gráfica.

Por tanto, y siguiendo a Tom Cummins (1988, 2004), a raíz de la "conquista visual" española y el despliegue de su "proyecto visual colonial" ocurrió un cambio figurativo en los vasos de madera inca; esto fue hacia nuevas formas coloniales más figurativas, polícromas y realistas que sus antecesoras tawantinsuyanas, las que ahora remitían a la realidad conocida por las sociedades andinas coloniales (como escena de baile indígena en Figura 4). Transformaciones visuales similares también ocurrieron en otros sistemas de soporte de origen precolombino; como los textiles tipo uncu $^{30}$ (Phipps 2005: 67-92) y tocapus $^{31}$ (Ziólkowski, Mariusz; Jaroslaw Arabas e Ian Szeminski 2008: 163-176).

\section{Detrás de las imágenes. Los discursos visuales de las criaturas fabulosas europeas en los "vasos de palo" policromados andinos coloniales}

La cosmología o contenido religioso precede a las pinturas [de los queros] Thomas Cummins 2004: 459

La "abstracción geométrica lineal incisa" sirvió, en los queros incaicos de madera (a razón de su facultad de registro "semasiográfico convencional", véase Figuras 3 a y 5), para recordar-por medio de bailes y retórica- hechos, mensajes y lugares colectivos específicos e importantes para la comunidad; como por ejemplo, la alianza que se formaba por medio del brindis con chicha entre el Inca y los jefes locales (Cummins 2004, 2007). Las primeras descripciones españolas de los queros de finales del siglo XVI d.C., específicamente de los "vasos de palo" de la transición ${ }^{32}$ (Flores Ochoa et al. 1998, Lizárraga 2009 e ir a nuestra Figura 3b), señalan que estos vasos contenían dibujos de animales pintados que estaban impresos en la memoria social andina, pues hacían recordar a los indígenas fiestas y cultos; siendo consideradas, por lo tanto, como significantes visuales cargados de memoria colectiva (contenedoras de una "memoria de palabras", según Frances Yates 2005). Debido a ello, estos significantes de animales fueron imágenes veneradas e incluso mochadas ${ }^{33}$ por las poblaciones locales (Albornoz 1967: 39 [1582] y Cobo 1956 [1653]). La presencia en los queros de varias imágenes que se guardaban en la memoria y que ayudaban para el recuerdo sugiere que un nivel de la memoria andina estaba amarrada a objetos y significantes visuales (Cummins 2007: 272). Por tanto los queros, incluso desde mucho antes de su giro pictórico dado a fines del siglo XVI d.C., ya eran objetos cargados de una memoria social que soportaban una imaginería compartida ${ }^{34}$, pues sus significantes visuales permitían recordar ritos o la entera "cosa" idolátrica del pasado.

Entonces las imágenes de los queros coloniales de madera policromados estuvieron cargadas de relatos de memoria social que permitieron recordar, a sus lectores indígenas (principalmente a las panacas incaicas descendientes), palabras, hechos y la cosa idolátrica misma. Debido a ello fueron considerados como objetos simbólicos con narrativas visuales vinculadas a las élites nativas (a modo de un "arte de élites"). Al decir de Lizárraga (2009), la "memoria andina colonial" de la nobleza incaica descendiente no fue uniforme (a modo de una clase homogénea y monolítica), pues cada panaca construía sus propias (sub)versiones y recuerdos de lo que debía y quería recordar; más aún cuando, debido a las prácticas de evangelización y lucha eclesial contra la idolatría nativa, las huacas de cada una de estas élites locales fueron aniquiladas por ser monstruosas (por contener al demonio mismo) y tener apariencia inca (de trazo esquemático y abstracto), generando con dicha destrucción un vacío simbólico y ceremonial -hiato- que pronto tenía que llenarse.

En los Andes del siglo XVI d.C. hubo animales que por su belleza o fealdad, "por su grandeza o monstruosidad", según Garcilaso de la Vega (1991: 234 [1609]), tuvieron significado especial entre las sociedades locales. Esta singularización permitió que muchas criaturas oriundas del Perú, como las "culebras gigantes" llamadas Amaru por ser "mucho más gruesas que el muslo de un hombre y largas" (Garcilaso de la Vega 1991: 234 [1609]), hayan sido respetadas y veneradas por las sociedades incaicas y andinas coloniales cumpliendo una función especial (sagrada) dentro de ellas. En efecto, el Amaru tuvo 


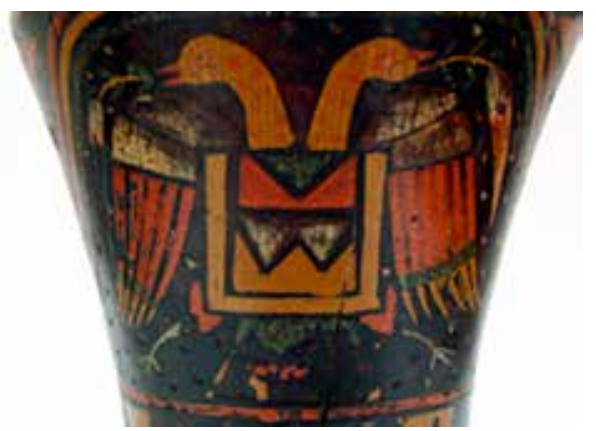

Figura 10. Detalle de ave bicéfala de cuello moteado como timbre heráldico debajo de motivo arco iris (kuychi) en llimpisccaquero del siglo XVII d.C. (Pieza MOMAC 77 del Museo Inka de la UNSAAC del Cuzco).

gran importancia ceremonial dentro del mundo amazónico y andino, ya que de acuerdo con los textos de Garcilaso de la Vega (1991 [1609]) y Guaman Poma (1980 [1615]) los indios adoraban "ídolos" en forma de serpiente conocidos como Amaru (véase también en Fernández 2004: 101; ir a Figura 11); razón por la que estos animales fueron representados en diversos rituales, narrativas y materialidades locales (como en los palacios imperiales por ejemplo ${ }^{35}$ ). Sin embargo para el "ojo conquistador de la época" la estética inca de estos "ídolos" locales dibujados en muros y otros soportes indígenas no caía dentro de sus marcos visuales renacentistas como tampoco en el decorum iconográfico de su referencia (de la pintasca), ya que los diseños prehispánicos, al ser de trazos geométricos lineales y toscos, fueron considerados por la matriz eurocéntrica como "monstruosos", pues no remitían a la realidad conocida por ellos sino más bien conducían al engaño ${ }^{36}$, teniendo por tanto que ser aniquilados -borrados- de la memoria visual indígena.

No obstante, en vez de que el resultado lógico de estas prácticas de extirpación de idolatrías y reemplazo simbólico de las mismas hubiese sido el hundimiento de las huacas y divinidades locales, el contenido y figura de estas jamás se perdió en el olvido, ya que fueron actualizadas por los mismos indígenas considerando la fuerza y popularidad que tenían, en el Viejo Mundo, las criaturas del bestiario medieval europeo.

Debido a que la pintasca europea del Cinquecento utilizó un conjunto de imágenes familiares para el "ojo español de la época", su difusión trajo consigo no solo la llegada de una nueva ontología de

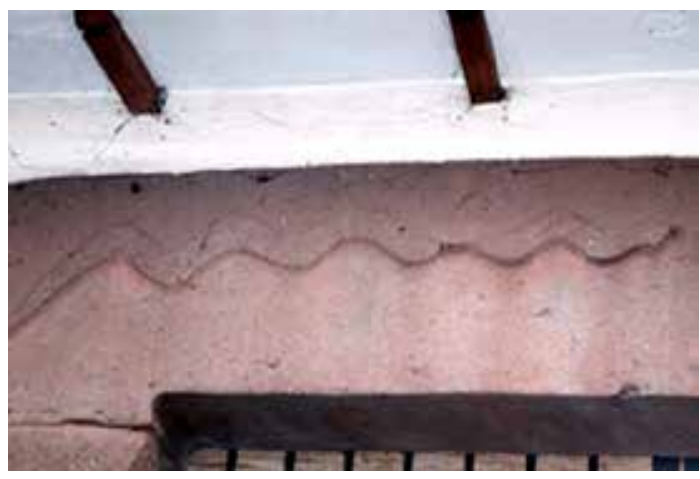

Figura 11. "Culebra gigante" Amaru de estética inca-serpiente esquemática y geométrica sin alas dispuesta horizontalmente. Dintel del Palacio Amaru Cancha (siglo XVI d.C., Cuzco).

la imagen ${ }^{37}$ (Merleau-Ponty 1957), sino también el arribo a los Andes sudamericanos de todo un nuevo repertorio iconográfico completamente diferente a los conceptos indígenas de representación; como por ejemplo las criaturas mitológicas grecorromanas de reproducción renacentista; el que no permaneció ajeno a la visualidad nativa, ya que dichos significantes fabulosos europeos ${ }^{38}$ sirvieron como modelos estéticos y mitológicos para reconfigurar y crear el nuevo imaginario andino colonial de apariencia colorida y figurativa dibujado en los llimpisccaqueros contemporáneos. Si bien este imaginario estuvo compuesto por figuras fabulosas derivadas del bestiario medieval, estas no correspondieron a verdaderas copias exactas o mecánicas de las mismas, sino a reconfiguraciones nativas -agenciaciones visuales- que se distanciaron formal y mitológicamente del vero ícono europeo (de la idea). Por tanto, y considerando este tipo de captura acaecido, se podría decir que los motivos iconográficos del bestiario medieval europeo triunfaron en la imaginación de las sociedades andinas coloniales.

A partir de esta apropiación y resemantización nativa hecha al bestiario medieval, tenemos en los llimpisccaqueros coloniales criaturas locales basadas en modelos estéticos de los imaginarios clásico y renacentista europeo (como sirenas (volver a Figura 8), centauros/sagitarios (Figura 3c), basiliscos (Figura 9), dragones (Figuras 3c y 7), aves bicéfalas (sean cóndores o águilas; véase Figura 10), cornucopias (Figura 12), querubines (ir a Figura 7) entre los más dominantes); que aparecen en las siguientes escenas de los queros coloniales de madera policromados (Tabla 1). 
Tabla 1. Cuadro de frecuencia de criaturas fabulosas del imaginario andino colonial en escenas figurativas de los llimpisccaqueros coloniales

\begin{tabular}{|c|c|c|c|c|c|}
\hline Temas & Motivo & Música & Enfrentamiento & & Caza \\
\hline Personajes & Arco Iris & Baile & Mitológico & Heráldica & Combate \\
\hline Sirena & $\mathrm{X}$ & $\mathrm{X}$ & & & \\
\hline Centauros/Sagitarios & $\mathrm{X}$ & & $\mathrm{X}$ & & \\
\hline Aves bicéfalas & $\mathrm{X}$ & & & $\mathrm{X}$ & \\
\hline Amaru dragontino & $\mathrm{X}$ & & $\mathrm{X}$ & & $\mathrm{X}$ \\
\hline Amaru basilisco & $\mathrm{X}$ & & & & \\
\hline
\end{tabular}

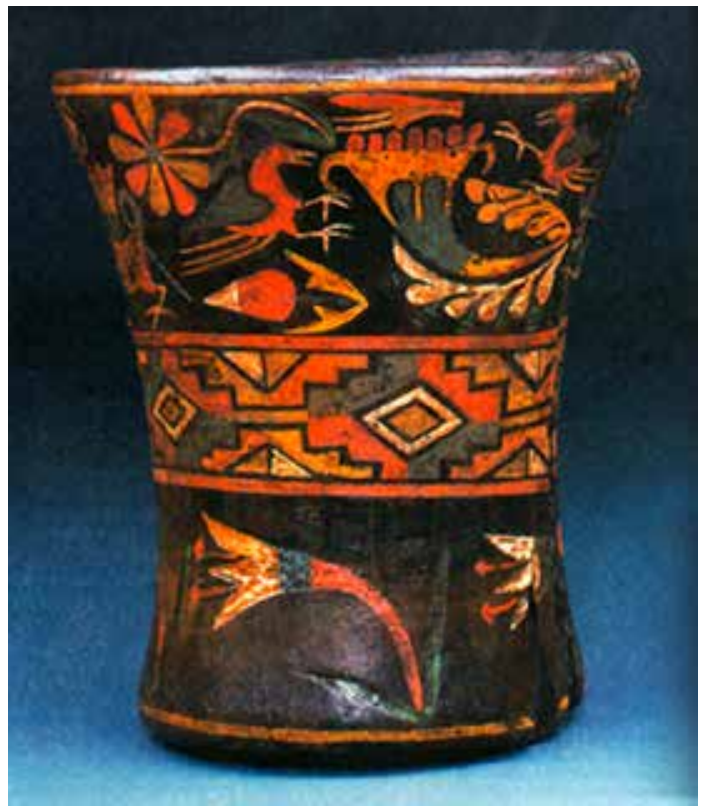

Figura 12. Cornucopia en campo superior de llimpisccaquero del siglo XVIII d.C. (colección del Museo Inka de la UNSAAC del Cuzco. Tomado de Flores Ochoa et al. 1998: 278).

A pesar 1) de la presencia de motivos iconográficos mitológicos de origen europeo y 2) el despliegue de la "política visual colonial" interesada en suplantar las creencias idólatras de los indios por medio de la fe cristiana, formas y contenidos prehispánicos de las huacas locales se mantuvieron tenaces en la memoria ceremonial indígena colonial, los que, a razón del impacto de la visualidad renacentista, fueron reconfigurados siguiendo los gustos y conocimientos de la estética y mitología conquistadora. Con dichas transformaciones pictóricas y cosmológicas las huacas locales pudieron mantenerse en vigencia al interior del mundo ceremonial andino contemporáneo. Por tanto, y de acuerdo con el corpus de llimpisccaqueros revisado, el imaginario andino colonial de corte figurativo y polícromo almacenó todos los impulsos visuales y mitológicos recibidos desde el escenario estético de la época (uno nuevo y de carácter multiforme); principalmente de dos tradiciones artísticas y cosmológicas diferentes: 1) una local con arcaísmos de raíces andinas prehispánicas y 2) otra de influencias clásicas y renacentistas europeas; a las que también debería sumarse la innovación y renovación hecha por los propios artistas locales (los querocamayocs).

Debido a que las criaturas del imaginario andino colonial basadas en formas fabulosas clásicas y renacentistas fueron recreadas dentro de espacios simbólicos diferentes a los acaecidos en el Viejo Mundo (como debajo del motivo arco iris, por ejemplo), las versiones andinas de los "motivos iconográficos" mitológicos europeos capturados de El Fisiólogo-Bestiario Medieval (como dragones, basiliscos, sirenas, aves bicéfalas, entre otros) no correspondieron, en los llimpisccaqueros coloniales, a simples significantes ingenuos o neutros, sino todo lo contrario, a "imágenes mentales" cargadas de significación religiosa y mitológica para sus principales usuarios y lectores: la élite andina colonial (único grupo indígena que podía materializar, en estos "vasos de palo" pintados, sus discursos míticos, ceremoniales y de memoria según Kuon 2003; Lizárraga 2009; Stastny 1993).

Entonces la evolución de las imágenes fabulosas del bestiario medieval en los queros coloniales de madera policromados (siglos XVI d.C. al XVIII d.C.) indica que estos significantes visuales sobrenaturales fueron anotados por las mismas sociedades andinas contemporáneas ${ }^{39}$ con la finalidad de soportar, estos "vasos de palo", relatos ceremoniales (y de culto) propios de cada panaca incaica descendiente (sus principales emisores). 


\section{A modo de conclusión: huacas disfrazadas}

Imagen e idea son mutuamente independientes

Stastny 1965: 12

Los queros coloniales de madera policromados llimpisccaqueros fueron verdaderos custodios de las palabras y las cosas creadas por la élite nativa contemporánea; las que, debido a las campañas europeas de extirpación de idolatrías, tuvieron tintes ceremoniales y memorísticos. A raíz del presente estudio iconográfico y del panorama histórico de producción acaecido en los llimpisccaqueros coloniales concluimos que las criaturas fabulosas clásicas del bestiario medieval de reproducción renacentista no pasaron inadvertidas en los Andes de los siglos XVI d.C. al XVIII d.C., ya que sus formas y atributos mitológicos fueron utilizadas como fuentes iconográficas y mitológicas, para que los querocamayocs e indios doctos contemporáneos pudiesen crear, luego de adaptarlas a sus propios marcos visuales de referencia, el imaginario andino colonial puesto en los queros coloniales de madera policromados. Debido a ello, los animales fabulosos de origen clásico que fueron dibujados y apropiados en estos "vasos de palo" pintados no permanecieron "puros" a sus registros europeos, sino, más bien, agenciados y cambiados según la estética indígena, ya que presentaron diferencias formales y de comportamientos que los distanciaron incluso del vero ícono transatlántico (del tipo iconográfico europeo). A raíz de este resultado, imágenes y contenidos de El Fisiólogo-Bestiario Medieval se instalaron por separado en los Andes del siglo XVI d.C.; gozando estas formas europeas de una profusa visibilidad y ubiquidad que les permitió sobrevivir y filtrarse en el mundo simbólico andino colonial.

La élite nativa contemporánea preparó en los llimpisccaqueros ${ }^{40}$ un imaginario basado en criaturas fabulosas clásicas y renacentistas europeas para actualizar, ante los suyos, el recuerdo de sus huacas locales de raíces incaicas. Debido a ello, las figuras fabulosas imaginadas europeas recién llegadas (centauros, sirenas, dragones, basiliscos, entre otras) tuvieron que ser anotadas y marcadas -"andinizadas"-dentro del paisaje simbólico local; razón por lo cual, las imágenes (mentales y gráficas) del bestiario medieval transatlántico cumplieron un rol importante en la formación de la nueva imaginería andina colonial; la que, valga resaltar, esta última nunca estuvo concluida, sino en un constante devenir, apropiación y retroalimentación. Entonces las "imágenes mentales" pensadas por "indios doctos" y querocamayocs de la época, influidas muchas de ellas por el bestiario medieval europeo e invisibles por ser propias de la cognición, generaron la imaginería nativa colonial que luego fue exteriorizada por medio del arte de los "vasos de palo" pintados.

Debido a este tipo de apropiación iconográfica nativa pensada y selectiva, el imaginario andino colonial puesto en los queros coloniales de madera policromados fue una creación intelectual que se basó, entre sus varias fuentes, en las criaturas fabulosas de los imaginarios clásico y renacentista europeos que produjeron, en los llimpiccaqueros, verdaderas ficciones iconográficas -agenciaciones-creadas y diseñadas de manera simuladora (disfrazada) para ocupar el hiato simbólico provocado por el aniquilamiento de las huacas locales de estética inca, a propósito de la conquista hispana. De este manera (mediante la recordación formal y de contenidos), las divinidades incas se hicieron indesvanescibles e inmortales en la memoria andina colonial (Yates 2005). Por tanto, la creación de estas phantasmatas "iluminadas" ${ }^{41}$ favoreció al resurgimiento de nuevas "imágenes mentales" de las huacas locales ahora de apariencia europeizante; con ellas, las élites andinas coloniales pudieron recordar sus cultos del pasado. En consecuencia, a raíz de la llegada del bestiario medieval a los Andes del siglo XVI d.C., el arte de memoria inscrito en los queros tuvo "un nuevo tren de vida" (Yates 2005: 151).

Entonces, lejos de que las imágenes textuales y gráficas de El Fisiólogo-Bestiario Medieval hayan destruido o menguado los hábitos de la memoria ceremonial indígena, estas sirvieron como fuentes (estéticas y mitológicas) para la creación en los queros coloniales de madera policromados (llimpisccaqueros) de una nueva imaginería andina colonial que reflejaba el pensamiento propio de su época en la que fue creada (como un típico momento histórico, un sello de su tiempo según Stastny 1965) de la permanencia de la memoria visual andina prehispánica en tiempos coloniales.

\section{Agradecimientos}

Por sus aportes de carácter científico y amistad "sin fronteras" quisiera agradecer a Alejandro Viveros El Melki y Pao Revilla Orías, con quienes discutí en un departamento frente al mar de Arica 
(2014) este ensayo presentado originalmente como ponencia para el IX Congreso Internacional de Etnohistoria. En Lima, y por su contribuciones artísticas y bibliográficas, a Diana Dávila Ortega (igracias por leer y comentar este manuscrito en su versión borrador!).

\section{Referencias Citadas}

Anómino

1951 [1586] Vocabulario y Phrasis en la Lengua General de los Indios del Perú, llamada Quechua, editado por G. Escobar. Universidad Nacional Mayor de San Marcos, Lima.

Anónimo

2000 El Fisiólogo. Bestiario Medieval. Ediciones Obelisco, Barcelona.

Arriaga, P. J.

1999 [1621] La Extirpación de la Idolatría en el Piru. Centro de Estudios Regionales Andinos "Bartolome de la Casas", Cuzco.

Bertonio, L.

1984 [1612] Vocabulario de la Lengua Aymara. CERES, Instituto Francés de Estudios Andinos (IFEA) y MUSEF, La Paz.

Boone, E.

1994 Introduction: Writing and Recording Knowledge. En Writing Without Words: Alternative Literacies in Mesoamerica and the Andes, editado por W. Mignolo y E. Hill Boone, pp. 3-26. Duke University Press, Durham, NC.

Cobo, B.

1956 [1653] Historia del Nuevo Mundo (tomos I y II), editado por F. Mateos. Ediciones Atlas, Madrid, España.

Cummins, T.

1988 Abstraction to Narration: Kero Imagery of Peru and the Colonial Alteration of Native Identity. Tesis para optar al grado de Doctor en Historia del Arte, Universidad de California, Los Angeles.

Cummins, T.

1995 Keros coloniales y el naufragio de "Nuestra Señora de Atocha": el problema de la cronología y el estilo heterogéneo. Revista del Museo e Instituto de Arqueología 25: 147-160.

Cummins, $\mathrm{T}$.

1998 El lenguaje del arte colonial: Imagen, ékrasis e idolatría. En Primer Encuentro Internacional de Peruanistas. Estado de los estudios histórico-sociales sobre el Perú a fines del siglo XX (2 volúmenes), vol. 2, pp. 23-43. Universidad de Lima, UNESCO y Fondo de Cultura Económica, Lima.

Cummins, $\mathrm{T}$.

2004 Brindis con el Inca. La Abstracción Andina y las Imágenes Coloniales de los Queros, Universidad Nacional Mayor de San Marcos, Universidad Mayor de San Andrés y Embajada de los Estados Unidos de América, Lima.

Cummins, $\mathrm{T}$.

2007 Queros, Aquillas, Uncus, and Chulpas: The Composition of Inka Artistic Expression and Power. En Variations in the expression of Inka Power, editado por R. Burger, C. Morris y R. Matos, pp. 267-311. Dumbarton Oaks, Washington D.C. De Mesa, J. y T. Gisbert.

1962 Historia de la Pintura Cuzqueña. Instituto de Arte Americano e Investigaciones Estéticas, Buenos Aires.

De Mesa, J. y T. Gisbert

2005 El Manierismo en los Andes. Memoria del III Encuentro Internacional sobre el Barroco. Unión Latina, La Paz.
Duviols, $\mathrm{P}$.

1967 Un inédito de Cristóbal de Albornoz: La Instrucción para descubrir todas las guacas del Piru y sus camayos y haciendas [ca. 1582]. Journal de la 1586] Societé des Americanistes 56(1): 7-39.

Fernández, C.

2004 Inca Garcilaso: Imaginación, Memoria e Identidad. Fondo Editorial de la Universidad Nacional Mayor de San Marcos, Lima.

Fernández Baca, J.

1971-1986 Motivos de ornamentación de la cerámica incaCuzco, tomos I y II, Librería Studium S.A., Lima.

Flores Ochoa J.; Kuon E. y R. Samanez

1997 Vasos de madera. Región del Lago Titicaca. Arkinka 25: 102-111.

Flores Ochoa J.; Kuon E. y R. Samanez

1998 Qeros. Arte Inka en Vasos Ceremoniales, Banco de Crédito del Perú, Lima.

Garcilaso de la Vega, Inca

1991 [1609] Comentarios Reales de los Incas, editado por C. Araníbar, 2 volúmenes, Fondo de Cultura Económica, México.

Gisbert, T.

1980 Iconografía y Mitos Indígenas en el Arte. Gisbert y Cía. Ediciones, La Paz.

González Holguín, D.

1952 [1608] Vocabulario de la Lengua General de todo el Perú llamada Lengua Qquichua o del Inca, prólogo de R. Porras Barnechea. Instituto de Historia de la Facultad de Letras de la Universidad Nacional Mayor de San Marcos, Lima.

González Carvajal, P. y T. Bray

2008 Introducción: Lenguajes Visuales de los Incas. En Lenguajes Visuales de los Incas, editado por P. González Carvajal y T. Bray, pp. 1-11. BAR, Oxford.

Greimas, A. J.

1971 [1966] Semántica estructural. Investigaciones metodológicas, Gredos Madrid.

Guaman Poma de Ayala, F.

1980 [1615] Nueva Coronica y Buen Gobierno, editado por Franklin Pease. Biblioteca Ayacucho, Caracas.

Guglielmi, N. (ed.)

1971 El Fisiólogo. Bestiario medieval. Editorial Universitaria, Buenos Aires.

Holland, A.

2008 Nueva Coronica: Tradiciones Artísticas Europeas en el Virreinato del Perú, Centro de Estudios Regionales Andinos "Bartolomé de las Casas", Cuzco.

Iwasaki Cauti, F.

1986 Las panacas del Cuzco y la pintura incaica. Revista de Indias XLVI (177): 59-74.

Kaulicke, $\mathrm{P}$

2003 Memoria Historiografiada y memoria materializada. Problemas en la percepción del pasado andino preeuropeo. Estudios Atacameños 26: 17-34. 
Kuon, E.

2003 Los Qeros en el marco del Barroco Andino. En Barroco Andino. Memoria del I Encuentro Internacional pp. 213220. Viceministerio de Cultura de Bolivia y Unión Latina, La Paz.

Lizárraga, M.

2009 Las élites andinas coloniales y la materialización de sus memorias particulares en los "queros de la transición" (vasos de madera del siglo XVI). Boletín del Museo Chileno de Arte Precolombino 14 (1): 37-53.

Lizárraga, $\mathrm{M}$.

2010 Los Queros Coloniales y el Imaginario Clásico y Renacentista. Tesis para optar al grado de Magíster en Estudios Latinoamericanos, Centro de Estudios Culturales Latinoamericanos de la Universidad de Chile, Santiago.

Martínez, J. L.

2008aDiscursos andinos coloniales: soportes, confluencias y transformaciones (Propuesta enviada al Concurso Nacional de Proyectos FONDECYT). Manuscrito en posesión del autor.

Martínez, J. L.

2008b Pensar y Representarse: Aproximaciones a Algunas Prácticas Coloniales Andinas de los Siglos XVI y XVII. En Lenguajes Visuales de los Incas, editado por P. González Carvajal y T. Bray, pp. 147-161. BAR, Oxford.

Martínez, J. L.

2011 ¿Cómo recordar? La construcción de las memorias andinas coloniales (siglos XVI y XVII). En Sobre los Incas, editado por L. Regalado de Hurtado y F. Hernández Astete, pp. 191-228. Instituto Riva-Agüero de la Pontificia Universidad Católica del Perú, Lima, Perú.

Malaxecheverría, I. (ed.)

1996 Bestiario Medieval. Ediciones Siruela, Madrid.

Mercado, M.

1991 Álbum de paisajes, tipos humanos y costumbres de Bolivia (1841-1869), Banco Central de Bolivia, Archivo Nacional de Bolivia y Biblioteca Nacional de Bolivia, La Paz.

Merleau-Ponty, M.

1957 Fenomenología de la percepción. Fondo de Cultura Económica, México D.F.

Mignolo, W.

1992 The Darker Side of Renaissance, Michigan University Press, Ann Arbor.

Mignolo, W.

1995 On the Colonization of Amerindian Languages and Memories: Renaissance Theories of Writing and the Discontinuity of the Classical Traditions. Comparative Studies in Society and History 34(2): 301-335.

Panofsky, E.

1983 Renacimiento y Renacimientos en el Arte Occidental, Alianza Editorial, Madrid.
Phipps, E.

2005 Rasgos de nobleza: los uncus virreinales y sus modelos incaicos. En Los incas, reyes del Perú, editado por T. Cummins, pp. 67-92. Banco de Crédito del Perú, Lima.

Quispe-Agnoli, R.

2008 Para que la Letra lo Tenga en los Ojos: Tocapu, Emblemas y Letreros en los Andes Coloniales del Siglo XVII. En Lenguajes Visuales de los Incas, editado por P. González Carvajal y T. Bray, pp. 133-145. BAR, Oxford.

Rostworowski, M.

1983 Estructuras andinas del poder. Ideología religiosa y política. Instituto de Estudios Peruanos, Lima.

Rowe, J. H

1961 The Chronology of Inca Wooden Cups. En The Essays in Pre Columbian Art and Archaeology, editado por Harvard University, pp. 317-341. Harvard University Press, Cambridge.

Rowe, J.H.

1976 El movimiento nacional Inca del siglo XVIII. En Tupac Amaru II-1780. Sociedad Colonial y Sublevaciones Populares, compilado por A. Flores Galindo, pp. 13-66. Retablo de Papel, Lima, Perú.

Salles-Reese, V.

2008 De Viracocha a la Virgen de Copacabana. Plural Editores e Instituto Francés de Estudios Andinos (IFEA), La Paz.

Salomon, F.

2001 How an Andean "Writing Without Words" Works. Current Anthropology 42(1): 1-27.

Stastny, F.

1965 Estilo y Motivos en el Estudio Iconográfico. Ensayo en la metodología de la Historia del Arte. Revista Letras 72-73: 5-18.

Stastny, F.

$1993 \mathrm{El}$ arte de la nobleza inca y la identidad andina. En Mito y Simbolismo en Los Andes. La Figura y la Palabra, compilado por H. Urbano, pp. 137-156. Centro de Estudios Regionales "Bartolomé de las Casas", Cuzco.

Taylor, G.

1987 Ritos y Tradiciones de Huarochirí: manuscrito quechua de comienzos del siglo XVII, Instituto de Estudios Peruanos (IEP) e Instituto Francés de Estudios Andinos (IFEA), Lima.

Warburg, A.

2005 Arte italiano y astrología internacional en el Palacio Schifanoia de Ferrara [1912]. En: El renacimiento del paganismo: aportaciones a la historia cultural del Renacimiento europeo, editado por F. Pereda, pp. 415-438. Alianza, Madrid.

Yates. F.

2005 El Arte de la Memoria, Editorial Siruela, Madrid.

Ziólkowski M.; Arabas J. e I. Szeminski.

2008 La historia en los Queros: Apuntes acerca de la Relación entre las Representaciones Figurativas y los Signos "Tocapus". En Lenguajes Visuales de los Incas, editado por P. González Carvajal y T. Bray, pp. 163-176. BAR, Oxford.

\section{Notas}

1 Como la pose ecuestre (véase "Conquista Milagro del S[eñ] or S[an]tiago mayor, apóstol de Jesucristo/en el Cuzco/" dibujado por Guaman Poma de Ayala (fl. 404 [406]) y “San Fernando recibiendo las llaves de Córdova" Anónimo del siglo XVIII d.C.) o el busto/retrato mimético (cf. "San Bartolomé" del círculo de José de Ribera -"El Spagnoletto"del siglo XVII d.C. y "San Juan Evangelista" de Melchor Pérez Holguín del siglo XVIII). 
2 Caballos, pantalones, sombreros, etc. (ver "Retrato de Felipe V convertido en Santiago". Anónimo de mediados del siglo XVIII d.C., "Santiago" del círculo de Leonardo Flores del siglo XVIII d.C. y "Santiago Apóstol”. Anónimo de finales del XVII d.C.).

3 Como calendarios zodiacales, almanaques mitológicos (el “Astrolabium Magnum"), la "Divina Comedia" de Dante Alighieri (1300-1318 d.C.), entre otros.

4 Aquí también podría señalarse: las versiones impresas e ilustradas (vg. Sandro Botticelli) de las criaturas fabulosas y moralizantes de "El Infierno" (Canto XII) de la Divina Comedia de Dante Alighieri (1300-1318 d.C.); como el centauro y minotauro.

5 Donde al Norte existía el Viejo Mundo (Europa, Asia y África) mientras que al Sur, a modo de contrapeso, un gran continente desconocido llamado Catígara, donde justamente merodeaban estas criaturas fabulosas (Anónimo 2000; Guglielmi 1971; Malaxecheverría 1996).

$6 \quad$ Imágenes que conmueven y se mantienen en la memoria (Yates 2005).

7 Revisar notas 1 y 2.

8 Como los centauros.

9 Una que ya se inclinaba a ser de carácter global y homogéneo.

10 Arte cercano a la realidad, que la imita. Para ello, revisar "Adoración de los Pastores" de Pieter Aersten (siglo XVI d.C.), "Epifanía" de Gregorio Gamarra (siglo XVII d.C.) o "San Francisco de Paula" de Manuel de Córdova (siglo XVIII d.C.).

11 Según Ricoeur: "Arte de interpretar los textos en un contexto distinto al de su autor y al de su auditorio inicial, con el afán de descubrir nuevas dimensiones de la realidad" (Rodolfo Cerrón Palomino comunicación personal 2014).

12 Arte que enseña a recordar y rememorar mediante técnicas pictóricas y retóricas, con la que se imprime en la memoria "lugares" e "imágenes" (Yates 2005).

13 A modo de una "codigofagia" según Bolívar Echevarría (Alejandro Viveros, comunicación personal 2014).

14 Sistemas de registro (de índole estatal como regional) que operaron como custodios de información religiosa y de temáticas vinculadas al poder, identidad y memoria social (Martínez 2011). Unidades discretas y sensibles portadoras de significación para las sociedades receptoras. Sistemas semióticos con particularidades y estéticas propias (Greimas 1971). No confundir con su traducción al inglés support: solo el soporte material.

15 "Vasos de palo" pintados de manera policromada del siglo XVI d.C. -"labrados de colores"- posiblemente con la técnica bajorrelieve conocida como "laca incrustada", pues, según González Holguín (1952: 213 [1608]), la palabra llimppicuna corresponde a "todas maneras de colores del lacre con que pintan vasos de madera".

16 Como los cuadros de Francisco de Zurbarán -"San Basilio"en la primera mitad del siglo XVII d.C.

17 Como la pintura al fresco "La defensa del cuerpo de Moisés" de Mateo Pérez de Alesio (ca. 1571-1572) en la Capilla Sixtina de Roma.

18 Pinturas de caballete y pincel en términos del Cinquecento (Cummins 1998); como aquellas expuestas, por ejemplo: en la "Adoración de los Pastores" de Pieter Aersten (en Museo Nacional de Arte de La Paz) o "La Virgen con el Niño" de Jan Metsys (esta última en: Mesa y Gisbert 1962: fig. 3).
Bolívar Echevarría.

20 Cronología relativa basada en el desarrollo artístico de los significantes visuales puestos en los queros (el estilo). Herramienta temporal usada debido a que la mayoría de los queros revisados y utilizados en la presente muestra $(\mathrm{n}=61)$ no provienen de excavaciones arqueológicas (piezas sin contexto).

21 Vasos de madera inciso-pintados de la segunda mitad del siglo XVI d.C. que combinan dos estilos diferentes, a saber: 1) bandas horizontales de significantes abstractos lineales de tradición incaica-cuzqueña con 2) diseños pintados de clara inspiración europea (en particular, representaciones zoomorfas polícromas de trato más figurativo, colorido y animado que sus pares lineales incásicos; véase ejemplos en Flores Ochoa et al. 1998). Son vasos que se encuentran a "medio camino" entre la tradición inca y colonial. Un par de estos ejemplares iguales (piezas hermanadas) fue hallado durante las excavaciones de John Rowe -en la tumba D- en Ollantaytambo (Cuzco) en 1934, en niveles estratigráficos relacionados -según el arqueólogo norteamericano- a la presencia de Manco Inca en el lugar después de la llegada hispana al Cuzco (esto fue entre 1536-1537). Más aún, la apariencia de estos "queros de transición" coincide con algunos relatos descritos por los primeros extirpadores de idolatrías como Cristóbal de Albornoz en Cuzco (ca. 1582) y Bartolomé Álvarez (en 1558); quienes informan acerca de que "en dichos vasos de palo donde pintaban animales y flores con gran habilidad y destreza, los indios recordaban sus ritos del pasado" (en Cummins 2004; Duviols 1967). Sin embargo, del corpus revisado, estos vasos de transición no incorporan figuras fabulosas europeas tomadas de $E l$ Fisiólogo-Bestiario Medieval, pues dicha apropiación recién ocurre en el siglo XVII d.C.

22 "La transmisión de la fuerza vital de una fuente animante, generalmente un dios regional o un antepasado, a un ser u objeto animado" (Taylor 1987: 24); por tanto, la imagen como vivificación divina de todas las cosas materiales: "el mismo dios". Fuerza vital o primordial que anima a todas las criaturas de la creación, por tanto, presente -según los extirpadores de idolatrías- en personas, momias de antepasados, animales, objetos inanimados como cerros, piedras o huancas (Cummins 2004; Rostworowski 1983).

23 Estética clásica compuesta por un arte imitativo o cercano a la realidad o naturaleza. Basado en ideas neoplatónicas que consideraban lo semejante como la mejor manera de acercarse a lo verdadero.

24 Véase figuras en Fernández Baca (1971, tomo I: 124).

25 Memoria entendida como "la parte sensitiva del alma que recoge las imágenes de las impresiones sensoriales; pertenece, por tanto, a la misma parte del alma a la que pertenece la imaginación, pero se halla también per accidens en la parte intelectual, por cuanto es en ella donde el intelecto actúa abstractivamente sobre los phantasmata" (Yates 2005: 91).

26 Similar al oficio de "PINTOR: LOS ARTIFICIOS, PINTOR, escultor, entallador, bordador, seruicio de Dios y de la Santa Yglecia" dibujado por Guaman Poma de Ayala (fl. 673 [687]).

27 Véase también dragón milenarista de cuatro (4) cabezas en nuestra Figura 3c. 
28 Ejemplos como este demuestran que si bien en los queros coloniales de madera policromados las imágenes fabulosas europeas están presentes en el mundo simbólico indígena, el contenido o tema mitológico inscrito en ellas varía.

29 Entendido aquí como el "motivo": la "unidad decimal" -la estructura- en la construcción del significante visual (Stastny 1965). También llamado por Stastny (1965: 13-14) como "tipo iconográfico", prototipo formal que no es esquema imitado mecánicamente ni un "cliché".

30 "Camiseta de indios" (González Holguín 1952: 355 [1608]).

31 "Los vestidos de lauores preciosos, o paños de lauor texidos" (González Holguín 1952: 344 [1608]); "tocapo, labor en lo que se brosla o texe en vasos y tablas" (Anónimo 1951: 84 [1586]).

32 Flores Ochoa et al. 1998 y Lizárraga 2009.
33 "Adoradas, o reverenciadas" (según Pablo Joseph de Arriaga 1999: 190 [1621]).

34 Por medio de imágenes en la memoria.

35 Véase dintel del Palacio Amaru Cancha en el Cuzco (nuestra Figura 11).

36 Por no tener estas formas claras.

37 La imagen como representación, como figuración de la realidad.

38 Véase Figuras 3c, 7, 8, 9 y 10.

39 Querocamayocs e indios doctos especialmente.

40 "Vasos de palo" usados en las ceremonias religiosas nativas donde se abrían canales de comunicación con los dioses locales.

41 Cargadas de información y que se explican por sí mismas (Yates 2005: 73). 
